\title{
Wybrane aspekty stosunków chińsko-francuskich w XXI wieku
}

\section{Selected Aspects of Chinese-French Relations in the $21^{\text {st }}$ Century}

\section{Abstract}

The relationship of the People's Republic of China with the French Republic was initiated in 1964 and has been constantly evolving since then. The $21^{\text {st }}$ century and the changes taking place in the international system have contributed to the growth of China's position in the international arena as a superpower, while France has been trying to maintain its dominant position in the European Union for two decades. Both countries have a lot in common and divide. The element that binds both countries together is their status in the UN Security Council, their ambivalent attitude to the superpower status of the United States, and the mutual willingness to expand economic cooperation. Among the factors that differ Beijing and Paris, there are rivalries in Africa and the approach to human rights. This does not change the fact that France is one of the main directions of China's European policy and makes it one of Beijing's most important political and economic partners. The international situation that both the Chinese and French governments have to face may contribute to a change in bilateral relations in the near future and the need for both sides to look for another partner in the region - in Europe through China and in Asia through France.

This article aims to highlight the most important aspects of Sino-French relations in the $21^{\text {st }}$ century, with particular emphasis on political and economic cooperation, especially in the context of the coronavirus pandemic. Outlining these aspects in the relations between China and France determines the construction of the article, which consists of three main parts corresponding to the relevant issues. The aim of this article is also to answer a number of research questions, such as: what were the most important controversial 
issues in Sino-French relations? Has the title of the most important politicians at the head of China and France influenced bilateral relations? Do relations with France's changing relations affect the international position of the PRC? Among the research materials used in this article, Polish, English and French-language literature can be mentioned, because access to Chinese materials is extremely difficult, including their translation into other languages. A number of research methods have been used to analyze this research problem, including historical analysis and description or decision method.

Keywords: China, France, economy, cooperation, $21^{\text {st }}$ century

\section{Китайско-французские отношения как элемент европейской политики Пекина в XXI веке}

\section{Аннотация}

Отношения Китайской Народной Республики с Французской Республикой берут свое начало с 1964 года и с тех пор постоянно развиваются. XXI век и изменения в международной системе способствовали росту позиции Китая на международной арене как сверхдержавы, в то время как Франция пытается сохранить свое доминирующее положение в Европейском Союзе в течение двух десятилетий. Обе страны имеют много общего, как и различий. Элементом, связывающим обе страны, является их статус в Совете Безопасности ООН, их двойственное отношение к сверхдержаве - Соединенным Штатам Америки - и взаимная готовность расширять экономическое сотрудничество. Факторы, которые отличают Пекин от Парижа, это соперничество в Африке и подход к правам человека. Тем не менее это не меняет того факта, что Франция является одним из основных направлений европейской политики Китая и одним из важнейших политических и экономических партнеров Пекина. Международная ситуация, с которой сталкиваются правительства Китая и Франции, может способствовать изменению двусторонних отношений в ближайшем будущем, а также тому, что обеим сторонам придется искать другого партнера в регионе - в Европе через Китай и в Азии через Францию.

Ключевые слова: Китай, Франция, экономика, сотрудничество, 21 век

\section{Wstęp}

Delacje Chińskiej Republiki Ludowej z Republiką Francuską zostały Zainicjowane w 1964 roku i od tamtego czasu ulegają ciągłej ewolucji. XXI wiek i zachodzące zmiany w systemie międzynarodowym przyczyniły się do wzrostu pozycji Chin na arenie międzynarodowej jako państwa 
mocarstwowego, natomiast Francja od dwóch dekad dąży do utrzymania swojej pozycji państwa dominującego w Unii Europejskiej. Oba państwa zarówno wiele łączy, jak i dzieli. Elementem spajającym podmioty jest ich status w Radzie Bezpieczeństwa ONZ, ambiwalentny stosunek do mocarstwowości Stanów Zjednoczonych, bogata historia i kultura, poczucie wyjątkowości oraz obustronna chęć rozbudowywania współpracy gospodarczej. Wśród czynników różniących Pekin i Paryż można natomiast wskazać rywalizację na terenie Afryki czy podejście do praw człowieka. Nie zmienia to faktu, że Francja stanowi jeden z głównych kierunków europejskiej polityki Chin i jest jednym z najważniejszych partnerów politycznych i gospodarczych Pekinu. Sytuacja międzynarodowa, z jaką musi zmierzyć się zarówno rząd chiński, jak i francuski, może przyczynić się w niedalekiej przyszłości do zmiany relacji bilateralnych i konieczności szukania przez obie strony innego partnera w regionie - w Europie przez Chiny i w Azji przez Francję.

Niniejszy artykuł ma na celu wskazanie najważniejszych aspektów w relacjach chińsko-francuskich w XXI wieku, ze szczególnym uwzględnieniem współpracy politycznej i gospodarczej, zwłaszcza w kontekście pandemii koronawirusa. Nakreślenie niniejszych aspektów w relacjach Chin i Francji warunkuje budowę artykułu, który składa się z trzech głównych części, odpowiadających poszczególnym zagadnieniom. Celem niniejszego artykułu jest także odpowiedź na szereg pytań badawczych, takich jak: jakie były najważniejsze kwestie sporne w relacjach chińsko-francuskich? Czy zmiana najważniejszych polityków stojących na czele Chin i Francji miało wpływ na relacje bilateralne? Czy zmieniające się relacje z Francją mają wpływ na międzynarodową pozycję ChRL? Wśród materiałów badawczych wykorzystanych w niniejszym artykule można wymienić przede wszystkim literaturę polsko-, angielsko- i francuskojęzyczną, gdyż dostęp do materiałów chińskich, w tym także do ich tłumaczeń na inne języki, jest niezwykle trudny. Do analizy niniejszego problemu badawczego został wykorzystany szereg metod badawczych, w tym analiza historyczna, opis czy metoda decyzyjna.

\section{Współpraca polityczna}

Model relacji chińsko-francuskich, który obowiązuje współcześnie, został opracowany w 1995 roku, gdy Francja pod zwierzchnictwem Jacquesa 
Chiraca w zamian za powstrzymanie się od krytyki polityki Chin zaczęła uzyskiwać liczne umowy gospodarcze.W 1997 roku oba państwa podpisały Wspólną deklarację o globalnym partnerstwie, która do teraz stanowi podstawę współpracy bilateralnej. Ponadto Chiny niejednokrotnie podkreślały, że Francja, jako jedno z pierwszych państw zimnowojennego Zachodu, uznało Chińską Republikę Ludową w 1964 roku. Był to okres określany jako „miesiąc miodowy" w relacjach chińsko-francuskich, szczególnie że Paryż w tamtym czasie bardzo chętnie podkreślał pozycję mocarstwową ChRL i popierał politykę jednych Chin - opowiadał się za przynależnością Tajwanu do Państwa Środka oraz potępiał ambicje niepodległościowe Tybetu (Kumoch, 2013).

Kwestią problematyczną w relacjach Chin i Francji jest podejście Pekinu do kwestii praw człowieka. Francja, jako państwo demokratyczne i orędownik praw człowieka, zapowiadała że w relacjach z Pekinem będzie zwracać uwagę swojemu partnerowi na kwestie z tym związane oraz konieczność respektowania praw człowieka jako elementu koniecznego do ukonstytuowania się statusu globalnego mocarstwa. Już w czasie zimnej wojny stanowisko Francji wobec rządów Mao Zedonga było oparte na stwierdzeniu, że chiński reżim stanowi dla bezpieczeństwa Azji zagrożenie podobne do japońskiego imperializmu. Niemniej, pomimo francuskich zastrzeżeń co do kwestii wolności i poszanowania praw człowieka w Chinach, przyjęto, że komunizm stanowi najprawdopodobniej jedyne rozwiązanie dla ChRL, by poprawić sytuację gospodarczą kraju. Szczególnie ważne znaczenie miała rewolucja kulturalna w Chinach i stanowisko Paryża wobec tego zagadnienia. Należy zauważyć, że radykalizm rewolucji kulturalnej został uznany za podkreślenie chińskiej specyfiki, polegającej na postrzeganiu chińskiego prawa oraz przestrzegania przez Chiny prawa, $w$ tym praw człowieka, w sposób zupełnie odmienny niż państwa Zachodu. Ponadto francuscy urzędnicy podkreślali, że to, co nie jest dobre dla Francji, może być dobre dla Chin i nadanie Chińczykom nowej moralności, zachowań czy działań, także tych uderzających w prawa człowieka, w imię danej ideologii pozwoliło Chinom utożsamiać się z potęgą i niepodległością (Liu, 2019). Wydarzenia, do jakich doszło na placu Tian’anmen w czerwcu 1989 roku, przyczyniły się do aktywizacji Francji, jeśli chodzi o przeciwdziałanie łamaniu praw człowieka przez chiński rząd. Francuscy dyplomaci przebywający na terytorium ChRL odegrali kluczową rolę w operacji Yellow Bird i udzielili pomocy kilkudziesięciu chińskim 
decydentom w ucieczce z kraju przez Hongkong do Francji, a następnie do Stanów Zjednoczonych (Peng, 2014). Był to szczególny przejaw francuskiej ingerencji w sytuację wewnętrzną Chin i udzielenie realnej pomocy osobom potrzebującym, które odczuwały zagrożenie ze strony chińskiego reżimu. W październiku 2000 roku podczas szczytu Unia Europejska-Chiny, Jacques Chirac wraz z Romano Prodim, szefem Komisji Europejskiej, odbył rozmowę z chińskim rządem, przedstawiając listę wykroczeń Pekinu wobec respektowania praw człowieka. Zasadniczą kwestią był fakt, że francuski prezydent nie reprezentował wówczas swojego państwa, a Unię Europejską, gdyż Francja pełniła prezydencję w UE (Kumoch, 2013). Wskazuje to jednoznacznie, że nie była to bezpośrednia krytyka działań Pekinu przez Paryż, a całą Wspólnotę. Rząd francuski już w 2003 roku wyszedł z inicjatywą na forum Unii Europejskiej, aby organizacja zniosła embargo na handel bronią, nałożone na Pekin po wydarzeniach z 4 czerwca 1989 roku (Cabestan, 2013, s. 331). Inicjatywa Francji nie spotkała się ze zrozumieniem ze strony Unii Europejskiej, podobnie jak w kolejnych latach: 2004 i 2005, gdy Paryż ponownie próbował przeforsować swój pomysł na forum organizacji. Francja, pomimo braku zniesienia embarga przez Unię Europejską na dostawy broni do Chin, zawarła z Pekinem umowę o sprzedaży przez firmę Dassault Aviation myśliwców Mirage oraz śmigłowców AS 365 IV Dauphine 2. Szczególne znaczenie ma fakt, że Francja, sprzedając ChRL śmigłowce Dauphine 2, wykorzystała pojęcie tak zwanych technologii podwójnego zastosowania (Parzymies, 2017, s. 376-377), które po odpowiedniej zmianie można wykorzystywać do celów militarnych. Takie stanowisko Francji wobec problemu poszanowania praw człowieka w Chinach jednoznacznie wskazuje, że francuski rząd jest świadom sytuacji w ChRL, szczególnie w Tybecie, Xinjiangu czy Hongkongu i często stara się podnosić tę kwestię na arenie międzynarodowej, ale jednocześnie nie zamierza rezygnować z realizacji swoich interesów gospodarczych i politycznych.

Kwestią związaną z prawami człowieka w Chinach jest sprawa Tybetu, w tym stosunku Francji do tego problemu. Wizyty Dalajlamy we Francji mają długą historię i sięgają 1982 roku. Wówczas odbyła się jego pierwsza podróż do Francji, podczas której przywódca Tybetańczyków ograniczył rozmowy z przywódcami politycznymi, poza spotkaniem z ówczesnym burmistrzem Paryża, którego funkcję pełnił wówczas Jacques Chirac, i skupił się na 
wykładach i naukach religijnych. Druga wizyta we Francji w 1993 roku miała zdecydowanie bardziej polityczny charakter, gdyż tybetański przywódca został przyjęty w Pałacu Elizejskim przez François Mitterranda. Podczas tej wizyty Dalajlama potępił działania władz ChRL oraz zaapelował do władz francuskich, by te wywarły presję na Pekin w celu zmiany polityki wobec Tybetu i Tajwanu. W 2008 roku Dalajlama przebywał z wizytą we Francji, ale prezydent Nicolas Sarkozy nie odbył spotkania z tybetańskim przywódcą, gdyż Dalajlama osobiście o nie nie zabiegał, ponieważ uważano, że takie spotkanie może zostać odebrane przez chiński rząd za prowokację. Dalajlama spotkał się z pierwszą damą, Carlą Bruni-Sarkozy, ministrem spraw zagranicznych Francji Berbardem Kouchnerem oraz sekretarzem stanu ds. praw człowieka Ramą Yade, którzy wzięli udział w inauguracji działalności buddyjskiej świątyni w Lodève (Lombart, 2016). Ponadto Dalajlama został przyjęty przez burmistrza Nantes ze szczególnymi honorami oraz wywieszoną na ratuszu miasta tybetańską flagą na znak solidarności miasta z Tybetem (Buhrer, 2017).W tymże roku wzrosło napięcie na linii Pekin-Paryż w związku z Letnimi Igrzyskami Olimpijskimi organizowanymi w Pekinie, kiedy to doszło do zamieszek w Tybecie, a Nicolas Sarkozy zapowiedział, że jego obecność na otwarciu Igrzysk będzie zależna od zmiany polityki Chin wobec Tybetu. Spotkało się to z krytyką ze strony władz w Pekinie, które oskarżyły Paryż o ingerencję w sprawy wewnętrzne ChRL. Nicolas Sarkozy zmienił jednak zdanie na temat swojej obecności na Igrzyskach Olimpijskich już parę tygodni później, podczas spotkania z prezydentem Chin $\mathrm{Hu}$ Jintao (Lakomy, 2012, s. 323). Pomimo swojej obecności w Pekinie podczas Igrzysk Olimpijskich w 2008 roku, stanowisko Nicolasa Sarkozy'ego w sprawie niepodległości Tybetu nie uległo zmianie, gdyż w grudniu 2008 roku w związku ze spotkaniem francuskiego prezydenta z Dalajlamą w Gdańsku został zerwany szczyt chińsko-europejski, który przyczynił się do zachwiania nie tylko relacji Pekinu z Paryżem, ale całą Unią Europejską. Francja w celu poprawy relacji z Chinami zobowiązała się w kwietniu 2009 roku do zaprzestania udzielania wsparcia Tybetowi (Cabestan, 2013, s. 333). Pomimo takiego stanowiska rządu francuskiego, w czerwcu 2009 roku Dalajlama otrzymał od Rady Miasta Paryża tytuł honorowego obywatela miasta, który został mu przyznany w 2008 roku. Pekin odebrał te wydarzenie za ingerencję w sprawy wewnętrzne państwa przez władze francuskiej stolicy, szczególnie 
że miało ono miejsce w krytycznym czasie dla chińsko-francuskich relacji, które nadal pozostawały napięte od 2008 roku (Galaud, 2009). Od tamtego czasu tybetański przywódca ograniczał swoje wizyty we Francji do rozmów na tematy religijne, kulturowe i środowiskowe. W 2016 roku Dalajlama przebywał z wizytą we Francji ${ }^{1}$, podczas której nie spotkał się z francuskim prezydentem Francois Hollande'm ani żadnym innym francuskim politykiem wysokiego szczebla. Został przyjęty przez parlamentarzystów w Senacie na zaproszenie Grupy Informacyjnej Senatu ds. Tybetu. Decyzja o braku organizacji spotkania Dalajlamy z najważniejszymi francuskimi politykami spowodowała, że deputowani do Senatu, którzy brali udział w spotkaniu z tybetańskim przywódcą, wezwali francuskiego prezydenta, premiera i ministra spraw zagranicznych do przyjęcia Dalajlamy, podkreślając znaczenie konieczności budowania procesu pokojowego między Tybetem a Chinami oraz wagę takiego spotkania jako symbolu poparcia Francji dla rozwoju społecznego i kulturowego w Tybecie (Le dalä̈-lama en visite..., 2016). Dalajlama spotkał się również z kandydatem na prezydenta, Emmanuelem Macronem, któremu już wtedy pogratulował przyszłego zwycięstwa w wyborach prezydenckich. Ponadto spotkał się z byłym ministrem sprawiedliwości Robertem Badinterem, którego wypowiedź na temat Chin i Tybetu wywołała kontrowersje: „Wiem bardzo dobrze, że dla Chińczyków jest to wilk ukryty za szatą mnicha [...] Widzę szatę mnicha, nie widzę wilka”, a także stwierdził, że „Tybet przechodzi zaprogramowane kulturowe ludobójstwo”. Paradoksalnie, Dalajlama ograniczył swoją krytykę wobec rządu chińskiego i stwierdził, że Xi Jinping chce reform, ale spotkają się one z oporem ze strony pozostałych chińskich decydentów (En France, le dalaï lama ménage la Chine..., 2016). Problem Tybetu zawsze będzie kwestią sporną w relacjach Chin ze społecznością międzynarodową, w tym w stosunkach z Francją, która jest uznawana za propagatora wolności, równości i braterstwa; jest świadoma, że utrata stosunków handlowych i politycznych z Chinami może mieć poważne konsekwencje nie tylko dla relacji bilateralnych, ale także w sferze międzynarodowej i stara się utrzymywać równowagę w tej kwestii,

1 Dalajlama przybył do Francji samolotem grupy Luxavuation, która została w 2014 roku zainicjowana przez Chińską Federację Przemysłu i Handlu i była wspierana przez chiński rząd. 
ograniczając spotkania o charakterze politycznym z tybetańskim przywódcą na rzecz tych o charakterze religijnym i kulturowym.

O tym, że Chiny były głównym kierunkiem francuskiej polityki zagranicznej w pierwszej dekadzie XXI wieku, świadczy fakt, że pierwsza wizyta zagraniczna prezydenta Nicolasa Sarkozy’ego odbyła się do Pekinu. Nowo wybrany prezydent Francji podkreślił wówczas mocarstwową pozycję ChRL, wskazał na rosnącą pozycję Chin w Afryce, ich znaczącą rolę w negocjacjach z Iranem i Koreą Północną na rzecz przeciwdziałaniu proliferacji broni masowego rażenia oraz poparł przynależność Tajwanu do Chin, przy jednoczesnym nacisku na konieczność przestrzegania przez Pekin praw człowieka i odejście od kary śmierci (Lakomy, 2012, s. 322). W listopadzie 2007 roku Nicolas Sarkozy i Hu Jintao podpisali Wspólną deklarację w sprawie zmian klimatu, która wspierała dialog na temat ochrony klimatu i zrównoważonego rozwoju obszarów miejskich, a środowisko i walka ze zmianami klimatycznymi stanowić miały jedną z głównych osi strategicznych współpracy chińsko-francuskiej. Znaczącą rolę w realizacji założeń umowy miało mieć chińskie Ministerstwo Budownictwa Mieszkaniowego Miast i Wsi i francuskie Ministerstwo Ekologii, Energii, Zrównoważonego Rozwoju. Miały one współpracować w ramach urbanistyki, transportu miejskiego i podróży, nauki i technologii budownictwa, wody, kanalizacji i oczyszczania ścieków. Ośrodkiem, który miał stać się centrum współpracy chińsko-francuskiej zostało wybrane miasto Wuhan i cała prowincja Hubei (France - Chine. Un partenariat..., 2010, s. 14).

Wygrana w wyborach prezydenckich François Hollande’a była krytykowana przez Chińczyków, gdyż zarzucano mu brak zainteresowania współpracą z Pekinem na skalę, jaka była charakterystyczna dla jego poprzednika, a także antychińskie nastawienie najbliższych współpracowników nowego prezydenta. Krytykowano przede wszystkim Arnauda Montebourga, który w czasie kampanii wyborczej we Francji wyrażał się negatywnie na temat zaniżania wartości chińskiego juana oraz przenoszenia produkcji do Chin przez francuskie firmy. Spowodowało to kryzys w relacjach chińsko-francuskich, który spotęgowała wizyta specjalnego wysłannika francuskiego prezydenta w Chinach, Laurenta Fabiusa. Chińscy decydenci odmówili spotkania z przedstawicielem Francji, co skutkowało szybkim powrotem Fabiusa do kraju. ChRL przyjęła jednak z zadowoleniem wyznaczenie Paula 
Jean-Ortiza przez Hollade’a na doradcę dyplomatycznego, szczególnie że był on dyrektorem Departamentu Azji we francuskim MSZ oraz specjalistą ds. Chin w Quai d'Orsay, a także wielokrotnie pracował we francuskiej ambasadzie w Pekinie. W związku z doświadczeniem dyplomaty władze chińskie zakładały, że uda mu się wpłynąć na politykę Hollande’a wobec Chin w taki sposób, by Paryż zrezygnował ze swoich nacisków na ochronę praw człowieka na rzecz realizacji interesów gospodarczych (Van Herpen, 2012, s. 8).

W 2014 roku, podczas obchodów 50. rocznicy nawiązania stosunków dyplomatycznych między Chinami a Francją, przedstawiciele Pekinu zapowiedzieli poparcie dla utrzymania francuskiej koncepcji „,niezależnej” polityki zagranicznej. Zarówno Paryż, jak i Pekin niezależność tę rozumiały jako realizację swoich interesów, a nie interesów Stanów Zjednoczonych, szczególnie w kontekście bezpieczeństwa międzynarodowego. Ponadto podkreślono znaczenie działalności Charlesa de Gaulle’a na rzecz rozwoju relacji z Chinami i zapowiedziano kontynuowanie polityki zorientowanej na stworzenie wielobiegunowego porządku świata (Ekman, Seaman, 2015, s. 27). Poprawa relacji chińsko-francuskich, szczególnie w latach 2014-2015, przyczyniła się do znaczącego wzrostu liczby wizyt polityków na wysokim szczeblu w obu państwach, co można było uznać za renesans „miesiąca miodowego", który miał miejsce w czasie prezydentury Chiraca.

Zarówno Chinom, jak i Paryżowi zależy na współpracy ze względu na agresywną politykę Donalda Trumpa, szczególnie w kontekście Bliskiego Wschodu. Chiny i Francja jako sygnatariusze porozumienia nuklearnego z Iranem z 2015 roku opowiadają się za utrzymaniem umowy, pomimo opuszczenia porozumienia przez USA oraz ukierunkowaniem na współpracę z Iranem na rzecz nieproliferacji broni masowego rażenia i zapewnienia bezpieczeństwa międzynarodowego (Maślanka, 2020, s. 2). Niemniej stanowisko Chin i Francji wobec irańskiego programu nuklearnego nie zawsze było tożsame. Pekin w przeciwieństwie do Paryża przeciwstawiał się nakładaniu kolejnych sankcji na Teheran. Wynikało to przede wszystkim z liczebności chińskich inwestycji w Iranie, szczególnie związanych z sektorem energetycznym i rosnącym uzależnieniem Chin od irańskiej ropy naftowej i gazu ziemnego. Francja natomiast w ramach międzynarodowych rozmów z Iranem nie reprezentowała tylko swoich interesów, ale przede wszystkim 
stanowisko całej Unii Europejskiej i nie stanowiła jedynego reprezentanta organizacji, gdyż musiała mieć na uwadze zdanie Niemiec i Wielkiej Brytanii.

Chiny stanowią jeden z najważniejszych kierunków polityki zagranicznej Emmanuela Macrona, który określa Francję jako tak zwane mocarstwo równowagi, które dąży do minimalizacji możliwości powstania nowego systemu międzynarodowego opartego na rywalizacji Pekin-Waszyngton (Maślanka, 2020, s. 1) i w tym celu zapowiedział swoje coroczne wizyty w Chinach oraz udzielenie rządowi w Pekinie wsparcia w kwestii walki ze zmianami klimatu i organizacji konferencji COP15 w sprawie różnorodności biologicznej, która została zaplanowana na jesień 2020 roku (Seaman, 2020, s. 70). Należy zwrócić uwagę na to, że polityka Macrona wobec Chin nie będzie miała wymiaru wyłącznie bilateralnego, ale będzie się on starał budować współpracę z Pekinem w szerszym jej aspekcie - europejskim. Dowodem tego miała być wizyta Emmanuela Macrona w Pekinie w październiku 2019 roku, kiedy to francuski prezydent wielokrotnie powtarzał, że jest on najważniejszym przedstawicielem Francji, ale nie całej Unii Europejskiej (Le Corre, 2019).

Za główny przejaw rywalizacji między Pekinem a Paryżem uznaje się wzmożoną aktywność Chin w Afryce, szczególnie w państwach francuskojęzycznych, które Francja uznaje za swoją strefę wpływów. Paradoksalnie, Pekin wspierał operację militarną Francji w Mali oraz wyrażał swoje zaniepokojenie sytuacją w wielu państwach afrykańskich mających silne związki z Paryżem. Ponadto, chińscy dyplomaci oraz inwestorzy działający w państwach afrykańskich wielokrotnie powtarzali, że działania, mające na celu ochronę własnych obywateli i inwestycji, są wynikiem obserwacji afrykańskiej polityki Paryża (Ekman, Seaman, 2015, s. 28). Emmanuel Macron zwrócił jednak uwagę, że Chiny wykorzystały naiwność europejskich przywódców, jeśli chodzi o politykę wobec Afryki, pozostawiając wiele państw samym sobie, co zostało wykorzystane przez Pekin i wiele chińskich inwestycji, które uważane są za krótkoterminowe, a mogą okazać się zagrożeniem dla bezpieczeństwa w regionie oraz czynnikiem uzależniającym tamtejsze rynki od Chin (Albert, 2019).

W kwietniu 2020 roku doszło do kryzysu w relacjach na linii PekinParyż, gdy francuska Rada Obrony Międzynarodowej zapowiedziała sprzedaż Tajwanowi wyrzutni do fregat La Fayette, które zakupiono wraz z samolotami bojowymi Mirage 2000 już na początku lat 90 . XX wieku. 
Ówczesna współpraca Francji i Tajwanu spowodowała kryzys w relacjach chińsko-francuskich do 1994 roku, gdy rząd francuski zrezygnował z handlu bronią z Tajpej (Cabestan, 2013, s. 330-331). Władze chińskie i ambasada ChRL złożyły w związku z zapowiedziami Francji oficjalny protest przeciwko francuskiej decyzji, ale nie spowodowało to zmiany planów Paryża (Maślanka, 2020, s. 2).

Można zatem zauważyć, że relacje chińsko-francuskie przypominają sinusoidę, której kształt jest uwarunkowany kolejnymi francuskimi administracjami. W XXI wieku szczególny wzrost intensywności współpracy chińsko-francuskiej wystąpił w czasie prezydentury Jacquesa Chiraca oraz Françoisa Hollande'a. Te dwie prezydentury charakteryzowały się przede wszystkim odsunięciem na drugi plan chińskiej polityki wobec respektowania praw człowieka na rzecz budowania partnerstwa politycznego, ale przede wszystkim gospodarczego. Prezydentura Nicolasa Sarkozy’ego stanowiła okres napięć i odejście od tak zwanego „miodowego miesiąca” w relacjach z Pekinem na rzecz aktywności Paryża, która była odbierana jako ingerencja w sprawy wewnętrzne ChRL. Od 2017 roku można zauważyć, że relacje Pekinu z Paryżem zmieniły się, głównie z powodu aktywności Emmanuela Macrona, który poczuwa się do roli przywódcy nie tylko francuskiego, ale także europejskiego, przez co Chiny odczuwają konieczność brania pod uwagę nie tylko współpracy bilateralnej Pekin-Paryż, ale również z pozostałymi 26 państwami Unii Europejskiej.

\section{Współpraca gospodarcza}

Chińska Republika Ludowa jest drugim, zaraz po Republice Federalnej Niemiec, eksporterem towarów do Francji oraz siódmym odbiorcą francuskich towarów (Maślanka, 2020, s. 1). Ukazuje to poziom współpracy gospodarczej między Pekinem a Paryżem, co jest szczególnie ważne w kontekście relacji chińsko-amerykańskich i wojny handlowej między państwami, gdyż stwarza dla Francji okazję do zbudowania strategicznego partnerstwa gospodarczego.

Dynamika importu towarów z Francji do ChRL stanowiła sinusoidę, niemniej nadal pozostaje ona na etapie ciągłego wzrostu od 2000 roku. Znaczący spadek w wymianie handlowej między Francją a Chinami można było zauważyć w 2009 roku, co było skutkiem napięć między prezydentem Sarkozy’m 


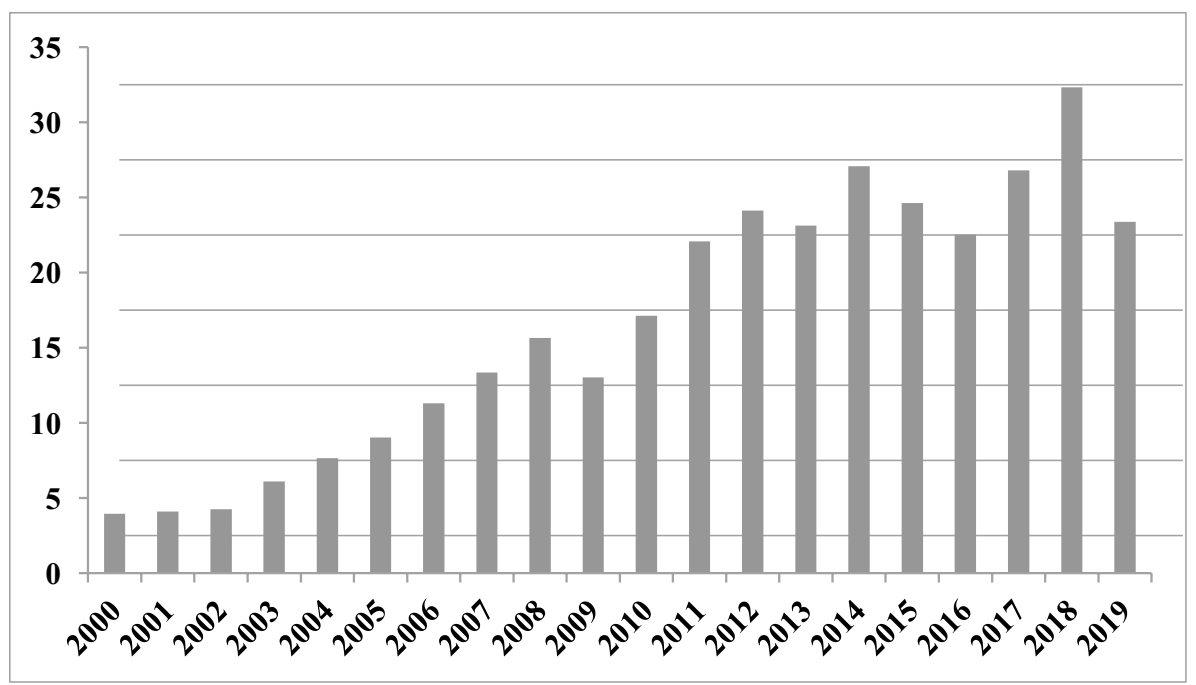

Wykres 1. Wartość importu towarów z Francji do Chin w latach 2000-2019 (w mld EUR)

Źródło: opracowanie własne na podstawie: Product Imports by China....

a Hu Jintao. Doszło wówczas do bojkotu francuskich towarów w ChRL, w tym sieci sklepów Carrefour, zablokowano wszelkie próby rozwijania francuskich inwestycji w Chinach oraz drastycznie spadło zainteresowanie Chińczyków wyjazdami do Francji, co odbiło się na sektorze lotniczym i turystycznym we Francji (Parzymies, 2017, s. 379-380). Od początku drugiej dekady XXI wieku import systematycznie wzrasta, z corocznymi wahaniami na poziomie 2-3 mld EUR, oprócz 2019 roku, gdy spadek sięgnął prawie 10 mld EUR. W 2020 roku tendencja spadkowa może się utrzymać ze względu na kryzys spowodowany pandemią koronawirusa.

Dynamika wzrostu wartości eksportu towarów z Chin do Francji jest na o wiele bardziej stabilnym poziomie niż import i również znajduje się w fazie ciągłego wzrostu. Dla przykładu, bywały lata, między innymi 2009, 2010, 2011 i 2019, gdy transfer produktów chińskich w znacznym stopniu przewyższał sprzedaż produkcji francuskiej do Chin. Ponadto chińskie inwestycje bezpośrednie stanowią znaczący odsetek wszystkich zagranicznych inwestycji we Francji i uczyniły Pekin ósmym największym inwestorem zewnętrznym zaraz po Stanach Zjednoczonych, Niemcach, Wielkiej Brytanii, Włoszech, 


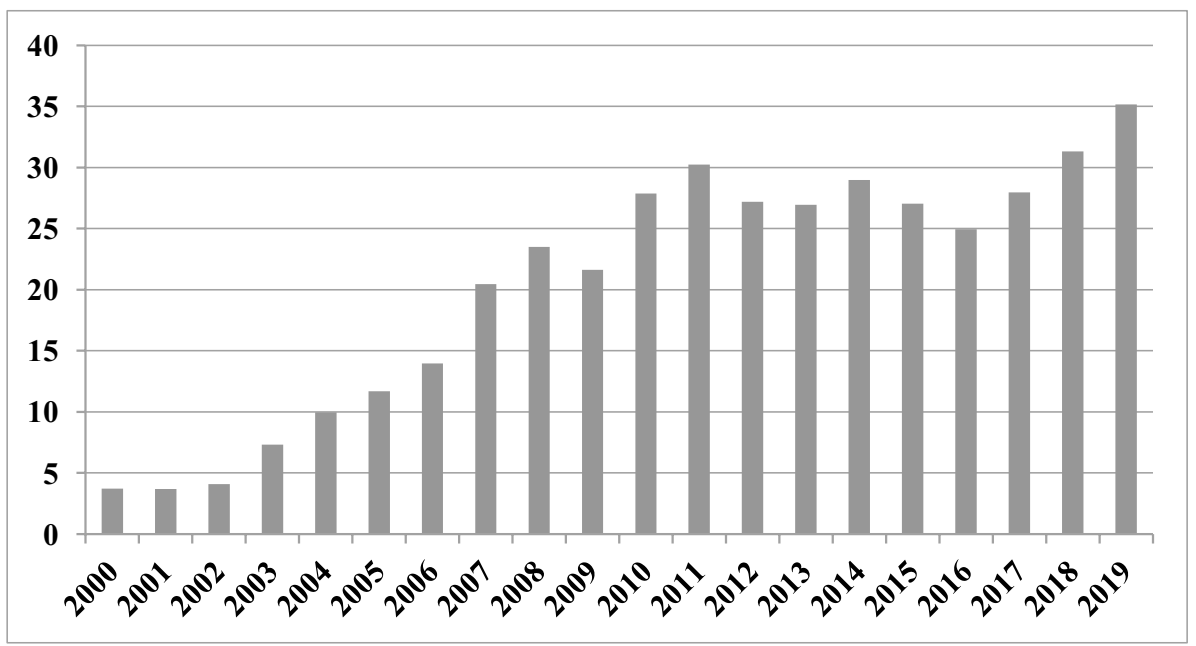

Wykres 2. Wartość eksportu towarów z Chin do Francji w latach 2000-2019 (w mld EUR)

Źródło: opracowanie własne na podstawie: Product Exports by France...

Holandii, Belgii i Szwajcarii. Inwestorzy z Chin oraz Hongkongu sprawują nadzór nad blisko 800 przedsiębiorstwami, gdzie szczególną rolę odgrywają przedsiębiorstwa związane z turystyką i rekreacją (Fosun International, Jin Jiang International Holdings), przemysł winiarski i spożywczy (Sanyuan Foods Co., Fosun Group, Profi tsun Holdings), odzieżowy (Fashion Group) oraz motoryzacyjno-lotniczy (Jilin Animation Institute, Dongfeng Motor Corporation) (Radomska, 2019, s. 175-176).

Jeśli chodzi natomiast o francuskie inwestycje w ChRL, funkcjonuje tam ponad 1100 przedsiębiorstw kwalifikowanych jako francuski kapitał. W przeciwieństwie do inwestycji chińskich, francuskie obejmują przede wszystkim przedsiębiorstwa zajmujące się energetyką, w tym jądrową (AREVA, Électricité de France, Suez, Schneider Electric, Veolia). Jest to wynik rosnącego zapotrzebowania Chin na wszelkiego rodzaju źródła energii, przez co stały się one atrakcyjnym partnerem dla Francji, jeśli chodzi o rozwój współpracy energetycznej. Duże znaczenie dla francuskich inwestycji w Chinach ma miasto Wuhan, które jest jednym z największych ośrodków gospodarczych Państwa Środka. W Wuhanie funkcjonuje największa liczba francuskich 
podmiotów gospodarczych związanych z sektorem motoryzacyjnym i lotniczym, w tym: Dongfeng Peugeot-Citroën Automobile, Electricfil Engine Components, Economic \& Technological Development Zone (Radomska, 2019, s. 178).

W 2013 roku prezydent ChRL Xi Jinping przedstawił inicjatywę Nowego Jedwabnego Szlaku, który miałby połączyć szlakami handlowymi trzy kontynenty: Azję, Europę oraz Afrykę. Początkowo Francja nie wykazywała zainteresowania chińskim projektem, argumentując, że nie była punktem docelowym zapowiadanej inwestycji. Podejście Paryża zmieniło się w 2016 roku, gdy dotarł pierwszy pociąg $\mathrm{z}$ kontenerami $\mathrm{z}$ Wuhanu do francuskiego Vénissieux (Radomska, 2019, s. 182). Spowodowało to, że rząd francuski zdał sobie sprawę z wartości chińskiej inicjatywy dla swojej gospodarki oraz perspektywy zwiększenia wzrostu wymiany handlowej między państwami, mając na uwadze nierówny bilans wymiany między Paryżem a Pekinem.

\section{Wpływ pandemii koronawirusa na stosunki Pekinu z Paryżem}

Na długo przed pandemią koronawirusa ChRL we współpracy z Paryżem wybudowała w Wuhanie laboratorium wirusologiczne klasy P4. Niemniej laboratoryjna współpraca chińsko-francuska zakończyła się w 2017 roku, gdy rząd chiński wykluczył francuskich specjalistów z prowadzonych badań. Skutkowało to oskarżeniami ze strony Paryża, że Chińczycy nie przestrzegają zasad bezpieczeństwa epidemiologicznego, a ich działania nie mają głównie celów medycznych, ale także militarne (Maślanka, 2020, s. 2).

Pandemia koronawirusa, trwająca od początku 2020 roku, przyczyniła się do osłabienia pozycji Unii Europejskiej w systemie międzynarodowym, szczególnie Francji, która stała się jednym z najbardziej dotkniętych skutkami epidemii państw w Europie (Znojek, 2020, s. 12)2. Pierwszy przypadek koronawirusa we Francji został odnotowany 25 stycznia u trzech osób, które wróciły z Wuhanu - jednej w Paryżu i dwóch w Bordeaux ${ }^{3}$. Wraz z pogarszającą się sytuacją epidemiczną, rząd francuski ogłosił ogólnokrajowy

2 Wśród najbardziej dotkniętych pandemią państw UE są Hiszpania, Francja, Włochy, Niemcy i Belgia.

3 W artykule została opisana sytuacja epidemiczna we Francji i ChRL w okresie od początku pandemii do czerwca 2020 roku. 
lock down w dniu 17 marca 2020 roku. 18 i 19 marca do Francji przybył pierwszy transport chińskich środków ochrony osobistej dla pracowników francuskiej służby zdrowia. W kolejnych tygodniach do Francji zaczęły przybywać kolejne dostawy pomocy solidarnościowej z Pekinu (Ekman, Seaman, 2015, s. 22)

Rozszerzanie się pandemii SARS-CoV-2 we Francji i na świecie skutkowało kryzysem w relacjach chińsko-francuskich na przełomie marca i kwietnia 2020 roku, gdy ambasador Chin w Paryżu umieścił w Internecie wpis, w którym nawiązał do teorii spiskowej, jakoby koronawirus powstał w Stanach Zjednoczonych, a nie w Chinach oraz oskarżył Francuzów o rasizm oraz pozostawienie chorych obywateli bez opieki medycznej. Skutkowało to wezwaniem chińskiego dyplomaty przez Jeana-Yvesa Le Driana, ministra spraw zagranicznych Francji, do złożenia wyjaśnień w tej sprawie (Wright, 2020, s. 3), a prezydent Emmanuel Macron oficjalnie stwierdził, że nie można do końca powiedzieć, że chiński rząd poradził sobie z epidemią koronawirusa.

5 czerwca 2020 roku Xi Jinping odbył rozmowę z Emmanuelem Macronem, podczas której podkreślił, że oba państwa powinny współpracować ze sobą w walce z pandemią, szczególnie w opracowaniu leków i szczepionki oraz udzielać wsparcia Światowej Organizacji Zdrowia. Prezydent Chin zwrócił uwagę, że Pekin i Paryż powinny skoncentrować swoją uwagę na Afryce, dla której pandemia może przynieść katastrofalne skutki. Podkreślił także, że ma nadzieję, iż po zakończeniu globalnego kryzysu współpraca gospodarcza między ChRL a Francją i całą Unią Europejską poszerzy się oraz że chiński rynek jest gotowy na europejskie inwestycje (President Xi Jinping Speaks..., 2020).

\section{Wnioski}

Zasadniczą zaletą relacji chińsko-francuskich jest brak odmiennych interesów między państwami, szczególnie w postaci udziału w konfliktach międzynarodowych, sporach terytorialnych czy aktywność we wrogich sojuszach. Niemniej Paryż zaczyna coraz częściej odbierać jako zagrożenie szybką modernizację chińskich sił zbrojnych oraz ekspansję gospodarczą Pekinu na jego terytoriach zamorskich na Południowym Pacyfiku i Oceanie 
Indyjskim. W 2019 roku na posiedzeniu Rady Praw Człowieka ONZ Francja zagłosowała za potępieniem Chin za działania w Xinjiangu oraz aktywność mającą na celu zakłócenie swobody żeglugi w Cieśnienie Tajwańskiej oraz Morzu Południowochińskim (Seaman, 2020, s. 69). Zarówno Chiny, jak i Francja posiadają ambicje do zmiany swojej pozycji mocarstwa regionalnego - Chiny wschodzącego, Francja - tego, który od kilkudziesięciu lat znajduje się w stagnacji. Poszerzanie swoich wpływów, szczególnie w Afryce i w innych państwach rozwijających się, może przyczynić się do stworzenia wizerunku Pekinu i Paryża jako podmiotów mających na celu współpracę i pomoc państwom słabszym, potrzebującym wsparcia w stabilizacji, niekonieczne militarnego, przy jednoczesnym umacnianiu uzależnienia od pomocy zewnętrznej ze strony Chin i Francji. Należy jednak mieć na uwadze fakt, że Chiny w tym przypadku znajdują się w zdecydowanie lepszej sytuacji, gdyż jako państwo nieposiadające historycznych zależności z państwami afrykańskimi, nie mogą zostać, w przeciwieństwie do Francji, oskarżone o politykę neokolonializmu.

Rysą na przyszłych relacjach chińsko-francuskich może być prowadzone przez Pekin szpiegostwo przemysłowe, które ukierunkowane jest głównie na sektor związany z lotnictwem, telekomunikacją czy programem kosmicznym. Obawy związane z zagadnieniem chińskiego szpiegostwa dotykają Francję od kilku lat, ale problem ten stał się jednym z tematów debat politycznych po tym, jak prezydent Stanów Zjednoczonych wezwał swoich europejskich sojuszników do wykluczenia chińskiego przedsiębiorstwa telekomunikacyjnego Huawei ze swoich rynków, oskarżając przy tym Pekin o szpiegostwo. Rząd francuski na początku lipca 2020 roku zapowiedział, że nie zabroni działać Huawei na swoim terytorium oraz kontynuacji wdrażania technologii 5G, ale zaleca niekorzystanie $\mathrm{z}$ jego usług (France won't ban Huawei, 2020).

Jeśli chodzi o znaczenie obu państw dla siebie, Chiny odbierają Francję jako jednego z najlepszych sojuszników w Europie, z którym Pekin może budować wspólny front przeciwko dominacji Stanów Zjednoczonych, choćby w Radzie Bezpieczeństwa ONZ. Niemniej, Chiny są świadome, że swojej polityki europejskiej nie mogą budować wyłącznie w oparciu o Paryż, ale muszą także udoskonalać swoją współpracę z innymi kluczowymi, szczególnie w kontekście gospodarczym, państwami, takimi jak np. Niemcy, 
Holandia, Belgia i Polska. Z perspektywy Francji Chiny odbierane są jako potencjalnie dobry odbiorca francuskich towarów oraz partner w budowaniu bezpieczeństwa międzynarodowego.

\section{MGR MARZENA MRUK}

Instytut Nauk Politologicznych

Wydział Nauk Społecznych

Uniwersytet Śląski w Katowicach

ul. Bankowa 11, 44-100 Katowice

mmruk@us.edu.pl

\section{Bibliografia}

Albert, E. (2019, 3 maja). Are China-France Relations in Trouble? Pobrane z: https:// thediplomat.com/2019/05/are-china-france-relations-in-trouble/.

Buhrer, J-C. (2017, 21 czerwca). Emmanuel Macron et le dalä̈-lama. Pobrane z: https:// www.letemps.ch/opinions/emmanuel-macron-dalailama.

Cabestan, J-P. (2013). Polityka zagraniczna Chin. Między integracją a dążeniem do mocarstwowości. Warszawa: Wydawnictwo Akademickie Dialog.

Ekman, A., Seaman, J. (2015). France and China: A not so 'special' relationship. W: M. Huotari, M. Otero-Iglesias, J. Seaman, A. Ekman (red.). Mapping Europe-China Relations A Bottom-Up Approach (25-30). Berlin: Mercator Institute for China Studies.

En France, le dalai lama ménage la Chine... et rencontre Robert Badinter (2016, 13 września). Pobrane z: https://www.lexpress.fr/actualite/monde/asie/en-france-le-dalai-lama-menage-la-chine-et-rencontre-robert-badinter_1830413.html.

France-Chine. Un partenariat pour l'avenir (2010, 18 października). Pobrane z: https:// www.diplomatie.gouv.fr/IMG/pdf/France_Chine_BAT_Light18_10_2010.pdf.

France won't ban Huawei, but encouraging $5 G$ telcos to avoid it: report (2020, 5 lipca). Pobrane z: https://www.reuters.com/article/us-france-huawei-5g/france-wont-ban-huawei-but-encouraging-5g-telcos-to-avoid-it-report-idUSKBN2460TT.

Galaud, F. (2009, 7 czerwca). Le dalaï lama, «citoyen d'honneur» de Paris. Pobrane z: https://www.lefigaro.fr/actualite-france/2009/06/07/01016-20090607ARTFIG00144-le-dalai-lama-citoyen-d-honneur-de-paris-.php.

Kumoch, J. (2013, 25 lutego). Polityka Francji wobec Chińskiej Republiki Ludowej. Pobrane z: http://www.polska-azja.pl/j- kumoch- polityka-francji-wobec-chinskiej-republiki-ludowej/.

Lakomy, M. (2012). Główne cele i kierunki polityki zagranicznej Francji w okresie poziomnowojennym. Katowice: Wydawnictwo Uniwersytetu Śląskiego.

Le Corre, P. (2019, 31 października). France and Germany must stand united if Europe is to exert any meaningful political and economic influence in its relations with 
Beijing. But for now, national interests prevail. Pobrane z: https://carnegieeurope.eu/ strategiceurope/80242.

Le dalä̈-lama en visite en France (2016, 12 września). Pobrane z: https://www.lefigaro. fr/politique/2016/09/12/01002-20160912ARTFIG00031-le-dalai-lama-en-visite-en-france.php.

Liu, K. (2019, 12 luty). Le PS et la Chine des années 1950 aux années 1980 : des <<regards>> aux $<<$ relations politiques $>>$. Pobrane $\mathrm{z}$ : https://jean-jaures.org/nos-productions/ le-ps-et-la-chine-des-annees-1950-aux-annees-1980-des-regards-aux-relations.

Lombart, G. (2016, 13 września). Dans le retro. Dalä̈-lama en France: des visites entre politique et spiritualité. Pobrane z: https://www.leparisien.fr/societe/dans-le-retro-dalai-lama-en-france-22-visites-entre-politique-et-spiritualite-12-09-2016-6114097. php.

Maślanka, Ł. (2020). Francja wobec Chin - stosunki po pandemii. Biuletyn PISM, 121, $1-3$.

Parzymies, S. (2017). Polityka zagraniczna Francji po zimnej wojnie. 25 lat w stużbie wielobiegunowości. Warszawa: Wydawnictwo Akademickie Dialog.

Peng, L. (2014, 1 czerwca). Tiananmen Square: the long shadow. Pobrane z: https://www. ft.com/content/4f970144-e658-11e3-9a20-00144feabdc0.

President Xi Jinping Speaks with French President Emmanuel Macron on the Phone (2020, 6 czerwca). Pobrane z: https://www.fmprc.gov.cn/mfa_eng/zxxx_662805/t1786503. shtml.

Product Exports by France from China. Pobrane z: https://wits.worldbank.org/CountryProfile/en/Country/CHN/Year/2016/TradeFlow/Export/Partner/FRA/Product/ All-Groups.

Product Imports by China from France. Pobrane z: https://wits.worldbank.org/CountryProfile/en/Country/CHN/Year/2010/TradeFlow/Import/Partner/FRA/Product/ all-groups.

Radomska, E. (2019). Bezpośrednie inwestycje zagraniczne we francusko-chińskiej współpracy gospodarczej w kontekście dwustronnych relacji Unii Europejskiej z Chinami. Sprawy Międzynarodowe, 72 (3), 171-196.

Seaman, J. (2020). France and US-China tensions: 69 bolstering multilateralism and amore autonomous Europe. W: M. Esteban, M. Otero-Iglesias (red.). Europe in the Face of US-China Rivalry. Madryt: Real Instituto Elcano.

Van Herpen, M.H. (2012). The foreign policy of president Hollande: u-turn or continuity? Cicero Fundation Great Debate Paper, 3, 1-10.

Wright, T. (2020, 8 lipca). Europe changes its mind on China. Pobrane z: https:// www.brookings.edu/wp-content/uploads/2020/07/FP_20200708_china_europe _wright_v2.pdf.

Znojek, B. (2020). Analiza poziomu restrykcyjności środków wprowadzonych w walce z pandemią - metodologia i wnioski. W: P. Sasnal (red.). Konsekwencje pandemii COVID-19 dla stosunków międzynarodowych (8-15). Warszawa: Polski Instytut Spraw Międzynarodowych. 